\title{
Welding in the World—update 2021
}

\section{John C. Lippold ${ }^{1} \cdot$ Ing Thomas Böllinghaus ${ }^{2} \cdot$ Américo Scotti $^{3}$}

Accepted: 1 January 2021 / Published online: 4 February 2021

(C) International Institute of Welding 2021

In 2020, Volume 64 of Welding in the World published 179 papers and over 2100 pages of fundamental and applied research associated with materials joining and allied technologies. The distribution of papers published in 2020, arranged by Technology Area, is shown in the accompanying figure. This includes papers from a special edition on Additive Manufacturing that was published in August.

Over 450 papers were submitted to the journal in 2020. The acceptance rate for these papers was $42 \%$ and average time to first decision was $\sim 50$ days. As shown in the chart below, the journal impact continues to increase based on both impact factor (IF) and CiteScore, with an anticipated IF of 2.0 expected for 2020. The number of paper downloads increased dramatically in 2020 to over 150,000, up $39 \%$ from 2019. Also, the time from paper submission to online publication was reduced to $\sim 210$ days. Further improvements are anticipated in 2021 with a goal of reducing time to online publication to 150 days.

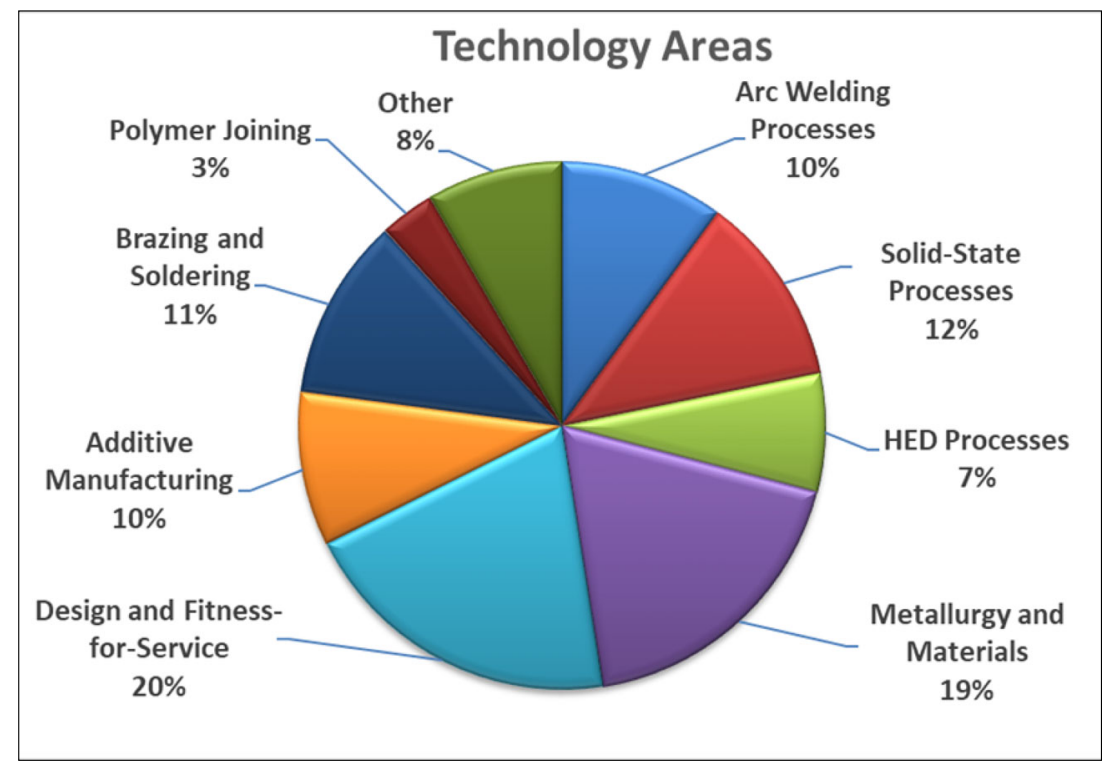

John C. Lippold

lippold.1@osu.edu

1 Welding Engineering Program, Department of Materials Science and Engineering, Ohio State University, Columbus, OH, USA
2 Department of Component Safety (Dpt.9), Bundesanstalt für Materialforschung und -prüfung, Berlin, Germany

3 University West, Department of Engineering Science, Production Technology West, Division of Welding Technology, Trollhättan, Sweden 
Starting in 2020, Welding in the World increased to 12 issues per year to accommodate the large number of papers that are being submitted and to allow more special issues and topical collections to be published. Despite the challenges created by the cancellation of the Annual Assembly in Singapore and the reliance on virtual working unit meetings, paper submission to WitW remained strong despite the drop in recommended papers. Also in 2020, a simplified keyword system was introduced that is now more closely linked to the profiles of reviewers in the Editorial Manager system. This change has facilitated the assignment of papers to the most appropriate reviewers.

In July 2020, Prof. Américo Scotti (Brazil/Sweden) replaced Prof. John Norrish from Australia who served as Interim Editor from July 2019. Professor Scotti's expertise is in the areas of welding processes and process modeling.
The Editorial Board currently consists of 39 members and assists the Editors with the pre-screening of open submission papers and the overall execution of the peer review process. There are now approximately 140 Principal Reviewers for WitW. The members of the Editorial Board are listed on the inside cover of the journal on the journal website. Principal reviewers who reviewed papers in 2020 are listed below.

The editors wish to thank all who contribute to the continued success of the journal including authors, working unit chairs and co-chairs, principal reviewers and members of the review panel, the Editorial Board, the IIW managing editor and staff, and the support staff at Springer. Over the last 5 years, the twofold increase in the number of papers published annually has required a tremendous effort by both the peer review panel and production staff.

Welding in the World - performance data

\begin{tabular}{|c|c|c|c|c|c|c|c|c|}
\hline & 2013 & 2014 & 2015 & 2016 & 2017 & 2018 & 2019 & 2020 \\
\hline Papers recommended by IIW WUs & 130 & 131 & 115 & 130 & 126 & 135 & 156 & 80 \\
\hline Open submission papers submitted & - & 49 & 172 & 278 & 256 & 305 & 380 & 420 \\
\hline Papers published & 82 & 84 & 90 & 114 & 120 & 120 & 160 & 179 \\
\hline Pages published & 945 & 923 & 932 & 1296 & 1296 & 1350 & 1902 & 2168 \\
\hline Total cites & 114 & 205 & 327 & 521 & 807 & 829 & 939 & 1,556 \\
\hline CiteScore & 0.61 & 0.89 & 0.93 & 1.26 & 1.52 & 1.62 & 2.60 & $\sim 3.40$ \\
\hline Downloads & 29,815 & 37,657 & 43,250 & 59,093 & 73,820 & 83,649 & 111,022 & 154,897 \\
\hline Science Citation Index (SCI) Impact Factor & 0.424 & 0.746 & 0.861 & 0.948 & 1.206 & 1.278 & 1.589 & $\sim 2.0$ \\
\hline
\end{tabular}

There is no updated data for Citescore or Impact Factor

Principal reviewers for WitW in 2020

\author{
Shaju ALBERT \\ M. AMIRTHALINGAM \\ Sudarsanam Suresh BABU \\ Margarita BAEVA \\ Zuheir BARSOUM \\ Jean Pierre BERGMANN \\ Eliot BIRO \\ Arun Kumar BHADURI \\ Carl CROSS \\ Bruno DE MEESTER \\ Jorge DOS SANTOS \\ Amitava DE \\ Thomas DUPUY \\ Stephan EGERLAND \\ Norbert ENZINGER \\ Majid FARAJIAN \\ Carolin FINK \\ Christof GERRITSEN \\ Gregor GOETT
}

Constantinos GOULAS
David GREWELL
Andrey GUMENYUK
André HÁLSIG
Stefan HEILMANN
Yoshinori HIRATA
Kai HILGENBERG
Akio HIROSE
Pat HOCHANADEL
Erika HODÚLOVÁ
Simon JAHN
Jolanta JANCZAK-RUSCH
Yongjuan JING
Sven JUETTNER
Thomas KANNENGEISSER
Doug KAUTZ
Hee Jin KIM
Damjan KLOBCAR
Damian KOTECKI

Arne KROMM
Veli KUJANPAA
Wenya LI
Hong LI
Tiesong LIN
John LIPPOLD
Stephen LIU
Xun LIU
Yuzhang LIU
Mauro MADIA
Milan MARONEK
Cécile MAYER
Peter MAYR
Geoff MELTON
Tobias MENTE
Anthony MURPHY
John NORRISH
Thomas NITSCHKE-PAGEL
Zengxi PAN




\section{Boyd PANTON}

Matthias PELKNER

Andreas PITTNER

Gerhard POSCH

Antonio RAMIREZ

Uwe REISGEN

Haishui REN

Michael RETHMEIER

Michael RHODE

Ian RICHARDSON

Klemens ROTHER

Ronald SCHNITZER

Volker SCHOEPPNER

Américo SCOTTI
Robert SHAW

Junjun SHEN

Aude SIMAR

Christof SOMMITSCH

Xiaoguo SONG

Stefano SORRENTINO

Jeffrey SOWARDS

Herbert STAUFER

Kazuo TATEISHI

Claus THOMY

Murali TUMULURU

Jari TUOMINEN

Asun VALIENTE BERMEJO

Vincent VAN DER MEE
Pedro VILAÇA

Petri VUORISTO

Guntram WAGNER

Elin WESTIN

Rebecca WHEELING

Stefanie WIESNER

Peer WOIZESCHKE

Lukas WOJARSKI

ChuanSong WU

Hua-Ping XIONG

Lei YE

Zhuyao ZHANG

Manuela ZINKE

Publisher's note Springer Nature remains neutral with regard to jurisdic-

tional claims in published maps and institutional affiliations. 